Florida A\&M University College of Law

Scholarly Commons@ FAMU Law

Journal Publications

Faculty Works

Summer 2013

\title{
Commonality Among Unique Indigenous Communities: An Introduction to Climate Change and Its Impacts on Indigenous Peoples
}

Randall S. Abate

Florida A \& $M$ University College of Law, randall.abate@famu.edu

Follow this and additional works at: http://commons.law.famu.edu/faculty-research

Part of the Environmental Law Commons, Human Rights Law Commons, Indian and Aboriginal Law Commons, and the International Law Commons

\section{Recommended Citation}

Randall S. Abate \& Elizabeth Ann Kronk, Commonality Among Unique Indigenous Communities: An Introduction to Climate Change and Its Impacts on Indigenous Peoples, 26 Tul. Envtl. L. J. 179 (2013).

This Article is brought to you for free and open access by the Faculty Works at Scholarly Commons @ FAMU Law. It has been accepted for inclusion in Journal Publications by an authorized administrator of Scholarly Commons @ FAMU Law. For more information, please contact linda.barrette@famu.edu. 


\title{
TULANE ENVIRONMENTAL LAW JOURNAL
}

\section{Commonality Among Unique Indigenous Communities: An Introduction to Climate Change and Its Impacts on Indigenous Peoples ${ }^{*}$}

\author{
Randall S. Abate ${ }^{\dagger}$ \\ Elizabeth Ann Kronk**
}

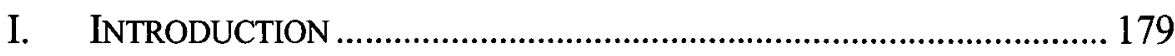

II. COMMONALITY OF EXPERIENCE .................................................... 181

III. LEGAL RESPONSES AT THE DOMESTIC, REGIONAL, AND

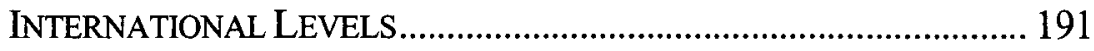

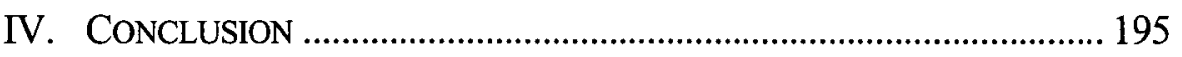

\section{INTRODUCTION}

This special Issue of the Tulane Environmental Law Journal explores how climate change affects the rights of indigenous peoples. Climate change is a global environmental problem caused by greenhouse gas emissions. Indigenous peoples generally contribute very limited quantities of greenhouse gases to the global atmosphere. Although the causes of climate change are global, the adverse impacts of this problem are disproportionately burdening indigenous peoples.

(C) 2013 Randall S. Abate and Elizabeth Ann Kronk.

* This Article is a republication with minor editorial changes - and with permission from Edward Elgar Publishing - of the authors' chapter in ClimATE CHANGE AND INDIGENOUS PeOPles: The SEARCH For Legal REMEDIES ch. 1 (Randall S. Abate \& Elizabeth Ann Kronk eds., 2013).

$\dagger \quad$ Associate Professor of Law and Director, Center for International Law and Justice, Florida A\&M University College of Law.

** Associate Professor of Law and Director, Tribal Law and Government Center, University of Kansas School of Law. Professor Kronk also serves as an appellate judge for the Sault Ste. Marie Tribe of Chippewa Indians, of which she is also an enrolled member. 
In recognition of the growing global problem of climate change, legal strategies to address climate change through mitigation and adaptation have been undertaken. ${ }^{1}$ This Issue recognizes that indigenous peoples are particularly vulnerable to climate change, both physically and legally, and addresses the challenges that these communities face in responding to climate change impacts.

The term "indigenous peoples" covers a widely diverse group of people within which no two communities of indigenous peoples are the same. ${ }^{2}$ Nevertheless, there are some commonalities that exist among groups of indigenous peoples. For example, most indigenous communities existed as autonomous communities and nations before contact with foreign societies. As a result of contact with foreign, dominant societies, many indigenous communities suffered generations of abuse and subjugation. Consequently, many modern indigenous communities lack the economic and political clout of dominant societies. Beyond this history of oppression, many indigenous communities also share unique legal and spiritual connections to their environment. Moreover, because of their unique histories, the law affecting indigenous communities is different in many localities.

Professor S. James Anaya explains:

The rubric of indigenous peoples includes the diverse Indian and aboriginal societies of the Western Hemisphere, the Inuit and Aleut of the Arctic, the aboriginal peoples of Australia, the Maori of Aotearoa (New Zealand), Native Hawaiians and other Pacific Islanders, the Sami of the European far North, and at least many of the tribal or culturally distinctive non-dominant peoples of Asia and Africa. They are indigenous because their ancestral roots are embedded in the lands on which they live, or would like to live, much more deeply than the roots of more powerful sectors of society living on the same lands or in close proximity. And they are peoples in that they comprise distinct communities with a continuity of existence and identity

1. Increasingly, the focus of international climate change responses is on adaptation strategies. However, "the adaptation response is deficient because it sees climate change as inevitable and implies that the only choice is to adapt to climate change or perish." Rebecca Tsosie, Indigenous People and Environmental Justice: The Impact of Climate Change, $78 \mathrm{U}$. COLO. L. REv. 1625, 1659-60 (2007); see also Dale Jamieson, Adaptation, Mitigation and Justice, in Perspectives on Climate Change: Science, Economics, Politics, Ethics 217, 225 (Walter Sinnott-Armstrong \& Richard B. Howarth eds., 2005) ("[T]he moral risk of a policy of 'adaptation only' is that it will hit the poor the hardest .....').

2. Indigenous Peoples Policy Brief: Still Among the Poorest of the Poor, World BanK 2, http://siteresources.worldbank.org/EXTINDPEOPLE/Resources/407801-1271860301656/HD NEN_indigenous_clean_0421.pdf (last visited Feb. 21, 2013). 
that links them to the communities, tribes, or nations of their ancestral past. $^{3}$

Although indigenous communities throughout the world differ, Part II of this Article addresses some of the commonalities generally found among indigenous peoples in greater depth: (1) increased vulnerability to climate change related to the location of indigenous communities; (2) a unique connection to the land for legal, spiritual and cultural reasons; (3) a history of colonization and oppression that has potentially increased the vulnerability of many indigenous communities; and (4) recognition under public international law that there are basic rights owed to indigenous communities. Recognizing these commonalities is crucial to understanding the legal mechanisms available to assist indigenous communities in adapting to the threats posed by climate change. Part III of this Article addresses three of these legal responses: (1) law suits based on procedural rights, (2) law suits based on common law legal principles, and (3) law suits based on public international law.

\section{COMMONALITY OF EXPERIENCE}

Before one can begin to consider the problem of climate change from a legal perspective as it impacts indigenous peoples, one must understand common attributes of many of the world's indigenous communities. By understanding commonalities among various indigenous populations; one can understand more readily the types of legal claims that these communities may bring. Moreover, as Professor Rebecca Tsosie explains:

[B]ecause climate change is often thought to be the inevitable byproduct of industrialization, rather than an intentional policy of national governments, and because the triggering events generally do not take place on or near the reservation and are not within the control of Native peoples as governments, the discussion in this area must go beyond tribal sovereignty and evaluate the rights of indigenous peoples as unique cultural and political groups. ${ }^{4}$

This is not to suggest that every indigenous community from the Arctic to the South Pacific has a shared experience. To the contrary, indigenous communities differ substantially and even indigenous communities located in the same country can vary widely. However, despite these differences, commonalities exist regarding the vulnerability of these

3. S. James ANaya, International. Human Rights and Indigenous Peoples 1 (2009).

4. Tsosie, supra note 1 , at 1628. 
communities to climate change and their relative contribution to the climate change crisis.

Although climate change is a global phenomenon affecting all areas and people, various regions and environments are affected very differently. ${ }^{5}$ Indigenous communities experience differing impacts depending on the region they inhabit-from the Arctic to the Andes to the Amazon, and from the islands of the Pacific Ocean to Canada's Pacific Rim. ${ }^{6}$

Unlike other populations, indigenous peoples have a tendency to be located in vulnerable locations throughout the world.' Indigenous communities are already dealing with impacts of climate change in their daily lives. ${ }^{8}$ For instance, the Amazon Rainforest, home to the Yanomami indigenous group, has experienced less rain, severe drought, and higher temperatures.' In Canada, indigenous groups such as the Tl'azt'en and the Gitga'at are experiencing unpredictable weather; increased temperatures have contributed to the largest insect infestation in North America, destroying millions of acres of pine trees that they rely on, affecting their food supply. ${ }^{10}$ In southern Africa, rising temperatures and increased wind speeds have resulted in vegetation loss." As a result, land customarily used for cattle and goat farming is no longer viable for traditional uses. ${ }^{12}$ Traditional farming practices in Asia and South America are also threatened by warming surfaces. ${ }^{13}$

5. Indigenous Peoples And Climate Change 6 (Jan Salick \& Anja Byg eds., 2007).

6. SuRvival InT'L, THe Most InCONVENIENT TRUTH of AlL: Climate Change and INDIGENOUS PEOPLE 1, 3-5 (2009), http://assets.survivalinternational.org/documents/132/survival climate_change_report_english.pdf.

7. alan Parker et al., Nw. Indian Applied Research INSt. (NIARI), Climate CHANGE AND PACIFIC RIM INDIGENOUS NATIONS 1-2, 19 (2006), http://academic.evergreen.edu/ g/grossmaz/IndigClimate2.pdf. See generally NaTIVE PeOPLES--NaTtve HomelandS Climate CHANGE WORKSHOP (Nancy G. Maynard ed., 1998); http://www.gcrio.org/OnLnDoc/pdf/native peoples.pdf (discussing the potential impacts of climate change on different Native homelands throughout the world).

8. See PARKER ET AL., supra note 7, at 1-2.

9. SuRVival INT'L, supra note 6, at 3; Daniel C. NePSTAD, The Amazon's Vicious

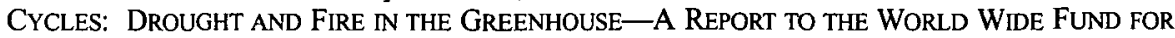
NATURE 4 (2007).

10. Indigenous Peoples and Climate Change, supra note 5, at 16; Andrea Carmen, Exec. Dir., Int'l Indian Treaty Council Admin. Office, Climate Change, Human Rights, and Indigenous Peoples, INT'L INDIAN TREATY COUNCIL 19 (Dec. 26, 2008), http://www.treatycouncil. org/PDF/HR\%20IPS\%20and\%20Climate\%20Change\%20corrfinal122708OHCHRa.pdf (submission to the United Nations High Commissioner on Human Rights).

11. Global Warming Solutions Are Hurting Indigenous People, Says U.N., MONGABAY.COM (Apr. 2, 2008), http://news.mongabay.com/2008/0402-redd_indigenous_people. html.

12. Id.

13. Id. 
In the Arctic, climate change is causing indigenous peoples to lose land and natural resources that are crucial to their subsistence lifestyle. ${ }^{14}$ Increasing temperatures related to climate change have caused melting of sea ice and permafrost, ${ }^{15}$ resulting in both global and local climate change impacts. For example, greenhouse gases that are trapped in the marshlands of the northeastern Siberian permafrost are being released because of permafrost ice melting, thereby exacerbating global climate change impacts. ${ }^{16}$ Climate change is also causing Arctic indigenous groups such as the Sami, Inuit, and Chukchi to suffer severe local impacts to their daily activities such as whaling, sealing, fishing, and reindeer herding. ${ }^{17}$ The Inuit's land is experiencing ice melting. ${ }^{18}$ Climate change has caused hunting, fishing, and travel in the Arctic to become more difficult, forcing some members to relocate after flooding. ${ }^{19}$ Reindeer herders report declining populations because the animals find it increasingly difficult to access food and are more likely to fall through melting ice. ${ }^{20}$ Some Arctic species, such as caribou, upon which indigenous peoples rely heavily for their survival, have migrated away from their traditional habitats and ranges due to shifts in weather patterns. $^{21}$

These impacts limit Arctic indigenous peoples' ability to rely on these species because the indigenous peoples, for legal reasons, may be

14. Id.

15. Daniel Cordalis \& Dean B. Suagee, The Effects of Climate Change on American Indian and Alaska Native Tribes, 22 NAT. RESOURCES \& ENV'T 45, 47 (2008) ("Alaska may be experiencing the impacts of global warming more than any other place on Earth, and Alaska Native tribes are among the first American populations to feel the effects of global climate change. Erosion and flooding affect 86 percent of Alaska Native villages to some extent, with the greatest effects felt along the coast." (citing U.S. GEN. ACCOUNTING OFFICE, GAO-04-142,

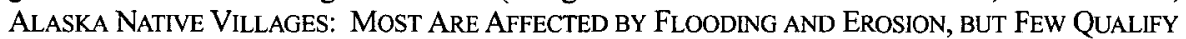
FOR FEDERAL ASSISTANCE (Dec. 2003), available at http://www.gao.gov/new.items/d04142.pdf).

16. See Mark Nuttall et al., Hunting, Herding, Fishing and Gathering: Indigenous Peoples and Renewable Resource Use in the Arctic, in ARCTIC Climate IMPACT AsSESSMENT $\S 12.2 .4 .1(2009)$.

17. See id. $\S 12.1-.2$.

18. SURVIVAL INT'L, supra note 6, at 3,10 n.11 ("Satellite data since 1978 show that annual average Arctic sea ice extent has shrunk by 2.7 (2.1-3.3)\% per decade, with larger decreases in summer of 7.4 (5.0-9.8)\% per decade." (quoting INTERGOVERNMENTAL PANEL ON Climate Change (IPCC), Climate Change 2007: Synthesis RePORT 30 (2007), available at http://www.ipcc.ch/pdf/assessment-report/ar4/syr/ar4_syr.pdf (internal quotation marks omitted))).

19. See Survival InT'L, supra note 6, at 3; Azadeh Ansari, 'Climate Change' Forces Eskimos To Abandon Village, CNN.com (Apr. 28, 2009), http://edition.cnn.com/2009/TECH/ science/04/24/climate.change.eskimos/index.html.

20. See Henry Huntington et al., The Changing Arctic: Indigenous Perspectives, in ARCTIC CLIMATE IMPACT ASSESSMENT, supra note $16, \S 3.1$.

21. See id. \$3.3. 
tied to specific areas of land, as explained below. ${ }^{22}$ As a result of the indigenous peoples' legal connection to the land, it may be impossible for communities to leave land that has been set aside for them in order to follow the changes in species' range land. This in turn decreases many indigenous communities' ability to adapt. In addition, some Arctic species are perishing as a result of climate change. ${ }^{23}$

Indigenous peoples living on low-lying island nations are also facing disproportionate negative impacts of climate change. ${ }^{24}$ As the sea ice at the poles melts due to increased temperatures related to climate change and the world's ocean levels rise, low-lying nations will disappear. ${ }^{25}$ Even a slight temperature increase of a few degrees can result in significant melting of the sea ice and, as a result, significant increases in the amount of water in the oceans. ${ }^{26}$ Indigenous peoples in these locations are, therefore, facing a loss of property, to which they may have vital cultural and spiritual connections, as the oceans swallow these low-lying island nations. ${ }^{27}$

Like the indigenous peoples of the Arctic, indigenous peoples living on low-lying islands are facing substantial changes to their biodiversity. ${ }^{28}$ Temperature increases have led to bleaching of coral reefs, which are of great importance to the Pacific Islands. ${ }^{29}$ Coral reefs are important to the region's biodiversity as a shelter for many organisms, and the decline in reef biodiversity is causing a decreased fish population. ${ }^{30}$ Because of climate change, indigenous peoples located in these areas of the world also may no longer be able to secure the species on which they have historically relied for subsistence. ${ }^{31}$ Indigenous food security is threatened in this region, as in other regions, because heat and saltwater

22. See43 U.S.C. $§ 1603$ (2006); Cordalis \& Suagee, supra note 15, at 45.

23. See Tsosie, supra note 1 , at 1640 .

24. PARKER ET AL., supra note 7, at 23-24. For a discussion of climate change impacts to indigenous peoples in Pacific island nations, see ClIMATE CHANGE AND INDIGENOUS PEOPLES: THE SEARCH FOR LEGAL REMEDIES, supra note *, chs. 16-19.

25. See Tsosie, supra note 1 , at 1636.

26. PARKER ET AL., supra note 7, at 23-24.

27. Tsosie, supra note 1, at 1636 ("However, the SIDS [small island developing states] are vulnerable to the catastrophic impacts of rising sea levels. Some of the smaller islands could perish altogether, but even the larger islands are in jeopardy. ... In these island areas, coastline erosion, loss of land and property, dislocation of people, and saltwater intrusion into freshwater resources could be catastrophic." (citations omitted)).

28. Id. at 1636-37 ("In addition, an increased prevalence and severity of storms linked to climate change would be especially devastating in such regions, as would be the inevitable loss of biodiversity for ocean species, including the loss of coral reefs and the fisheries in these areas.").

29. PARKER ET AL,, supra note 7, at 16.

30. Id. at 24 .

31. See id. at 2,5 . 
intrusions are negatively affecting agriculture. ${ }^{32}$ Therefore, although indigenous peoples of the Arctic and low-lying nations are very different, commonality in their experience exists regarding climate change impacts to their lands and to the species on which they have traditionally relied for subsistence.

Perhaps the greatest paradox is that some climate change mitigation efforts are actually compounding the plight of indigenous peoples. ${ }^{33}$ Many initiatives, such as biofuels, hydroelectric power, forest conservation, and carbon offsets, which are generally positive measures to address climate change, are often implemented at the expense of indigenous peoples' rights. ${ }^{34}$ In this way, many indigenous communities are threatened by initiatives designed to benefit foreign communities.

Biofuels are an alternative source of energy promoted as a climate change mitigation initiative, but it is estimated that 60 million indigenous peoples will be displaced because of biofuel expansion. ${ }^{35}$ Indigenous populations in Indonesia and Malaysia have lost forest land because of palm oil plantation expansion. ${ }^{36}$ The Guarani tribe of Brazil is losing its ancestral land as Brazil expands sugar cane cultivation to convert into ethanol to meet energy security objectives. ${ }^{37}$

Hydroelectric power is another source of alternative energy and is being used as part of climate change mitigation efforts. ${ }^{38}$ Yet hydroelectric dams sometimes occupy indigenous land, destroying their communities. $^{39}$ In Borneo, Malaysia, for example, 10,000 indigenous peoples were displaced by the Bakun dam project, flooding 700 square kilometers of surrounding land. ${ }^{40}$

Forest conservation measures and carbon offsets are other initiatives to prevent deforestation and mitigate climate change impacts, but also involve displacing indigenous peoples or otherwise restricting their rights

32. Id. at $22-23,25,33$.

33. Global Warming Solutions Are Hurting Indigenous People, Says U.N., supra note 11.

34. SURVIVAL INT'L, supra note 6, at 1, 5-9.

35. Id. at 5 .

36. Ellie Brown \& Michael F. Jacobson, Ctr. for Sci. Pub. Interest, Cruel Oll: How Palm Oil Harms Health, Rainforest \& Wildlife 17, 21-22 (2005), available at http://www.cspinet.org/palm/PalmOilReport.pdf.

37. SuRVIVAL INT'L, supra note 6, at 5-6; "Foreigners in Our Own Country": Indigenous Peoples in Brazil, AMNESTY INT'L (Mar. 30, 2005), http://www.amnesty.org/en/library/asset/AMR 19/002/2005/en/b75901bl-d526-11dd-8a23-d58a49c0d652/amr190022005en.pdf.

38. See generally JOHN D. ECHEVERRIA ET AL., RIVERS AT. RISK: THE CONCERNED CITIZEN's GUIDE TO HYDROPOWER 4-7 (1989) (describing how dams harm rivers).

39. SURVIVAL INT'L, supra note 6, at 6-7.

40. Id. at 6; see Sean Yoong, Borneo Tribe Loses Land Case in Top Malaysia Court, DESERET NEwS (Sept. 8, 2011), http://www.deseretnews.com/article/700177219/Borneo-tribeloses-land-case-in-top-Malaysia-court.html. 
or traditional use of land or natural resources. ${ }^{41}$ In Kenya, thousands of Ogiek community members were forced to abandon their homes in the Mau Forest because of the country's conservation efforts, despite the tribe's sustainable existence there for hundreds of years. ${ }^{42}$ Moreover, carbon-offsetting initiatives, including reducing emissions from deforestation and degradation (REDD), violate indigenous rights. ${ }^{43}$ Apart from concerns regarding the impacts to indigenous peoples, REDD faced many implementation challenges, which led to the creation of "REDD+" as a more effective and flexible form of REDD for the future. ${ }^{44}$ REDD's evolution into REDD+ in the years preceding the Fifteenth Conference of the Parties to the United Nations Framework Convention on Climate Change in Copenhagen in 2009 "involved a transition to an enhanced, broad-based approach that includes conservation, sustainable forest management, and forest carbon stock enhancement."*s

A large portion of the world's forests contemplated in REDD+ schemes belong to indigenous peoples, who fear that such initiatives will cause forced evictions, prevent access, threaten traditional agriculture activity, destroy biodiversity, and violate their rights to their land and natural resources. ${ }^{46}$ Under REDD+, developing countries are encouraged to protect their forests, because they can sell stored carbon from the forests as credits to developing countries to offset their carbon emissions. ${ }^{47}$ However, until recently, indigenous peoples in developing countries have had limited or no participation in decision-making processes such as REDD+. ${ }^{48}$

41. SURVIVAL INT'L, supra note 6, at 7-9.

42. Id:; Kevin J. Kelley, Act on Threat to Climate, Raila Appeals, DaILY NaTION, Sept. 26, 2009, http://www.nation.co.ke/News/-/1056/663936/-/unej3w/-/index.html.

43. See Stephanie Baez, Note, The "Right" REDD Framework: National Laws that Best Protect Indigenous Rights in a Global REDD Regime, 80 ForDHAM L. REV. 821, 846-51 (2011).

44. Randall S. Abate, A Tale of Two Carbon Sinks: Can Forest Carbon Management Serve as a Framework To Implement Ocean Iron Fertilization as a Climate Change Treaty Compliance Mechanism?, 1 SEATTLE J. ENVTL. L. 1, 6 (2011).

45. Id. (citing FOOD \& AGRIC. ORG. (FAO) \& THE CTR. FOR PEOPLE \& FORESTS, FORESTS ANd Climate Change AFter Copenhagen: AN ASIA-PACIFIC PERSPECTIVE 6 (2010), available at http://www.rightsandresources.org/documents/files/doc_1717.pdf).

46. SURVIVAL INT'L, supra note 6, at 8-9.

47. Id. at 8 .

48. Estebancio Castro Diaz, Climate Change, Forest Conservation and Indigenous Peoples Rights 2 (Global Forest Coal. Discussion Paper No. 2007/WS.6), available at http:// www.un.org/esa/socdev/unpfii/documents/EGM_cs08_diaz.doc ("[D]espite recent developments in international law in relation to Indigenous Peoples rights, Indigenous Peoples still have limited or in some instances no participation in the decision-making processes of the United Nations Framework Convention on Climate Change (UNFCCC)."). For a discussion of the potential adverse impacts of REDD on indigenous peoples, see CLIMATE CHANGE AND INDIGENOUS PEOPLES: THE SEARCH FOR LEGAL REMEDIES, supra note *, chs. 7-9. 
In December 2011, at the Sixteenth Conference of the Parties to the United Nations Framework Convention on Climate Change in Durban, an alternative to the traditional forms of REDD+ through UNFCCC negotiations emerged. ${ }^{49}$ This new approach to considering REDD, known as "Indigenous REDD+," emphasized that REDD+ should be designed to ensure that financial benefits from REDD projects flow directly to the indigenous communities, emphasize the ability of indigenous peoples to preserve forests, and recognize that REDD+ must be implemented with clear assurances of land ownership in all REDD+ activities. $^{50}$ Coordinator of Indigenous Peoples of the Amazon Basin (COICA), the chief proponent of Indigenous REDD+, expressed concern that REDD+ as currently conceived may perpetuate an improper conception that forests are nothing more than carbon sinks and enable the potential for abuse of indigenous populations through inequitable REDD+ arrangements. ${ }^{\text {I }}$ COICA asserts that Indigenous REDD+ arrangements must remain outside of international carbon markets to avoid measures that exploit indigenous peoples or restrict their access to forests because such measures may be cheaper than holistic forest protection efforts that allow continuation of indigenous uses. ${ }^{52}$

In addition to the commonality of the threat from climate change and mitigation efforts, many indigenous communities also share a unique connection to the land that is often not present in the dominant society. ${ }^{53}$ This connection is evident through indigenous communities' legal protections and their spiritual and cultural ties to the land. ${ }^{54}$ Following colonization from outside societies, many indigenous communities found themselves relegated to certain territories within the dominant nation. For example, in the United States, many tribal nations were removed from their traditional homelands and placed within reservation boundaries that may or may not have been located within the tribe's

49. Summary of the Durban Climate Change Conference, 12 EaRTH NegOTIATIONS BULL., Dec. 13, 2011, at 1, 18, available at http://www.iisd.ca/download/pdf/enb12534e.pdf.

50. United Nations Framework Convention on Climate Change Webcast, Press Conference: Coordinating Body of Indigenous Organizations of Amazon Basin (COICA): Alternative Indigenous REDD+: Territories of Harmonious Life To Cool the Planet, UNITED Nations Framework Convention on Climate Change (Dec. 1, 2011), http:/unfccc4.metafusion.com/kongresse/cop 17/templ/play.php?id_kongresssession=4324\&theme=unfccc.

51. Id.

52. Id.

53. Cordalis \& Suagee, supra note 15 , at 45 ("Climate change will affect American Indian tribes differently than the larger American society. Tribal cultures are integrated into the ecosystems of North America, and many tribal economies are heavily dependent on the use of fish, wildlife, and native plants.").

54. See Frank Pommersheim, The Reservation as Place: A South Dakota Essay, 34 S.D. L. REv. 246, 250 (1989). 
traditional homeland.5.$^{55}$ As American federal Indian law developed, many of the legal rights possessed by these tribal nations were tied to the reservations where the tribes were relocated. ${ }^{36}$ As a result, American tribal nations now have a strong legal interest in the land on which they reside. ${ }^{57}$ Additionally, the reservation boundaries often place limitations on the legal rights enjoyed by such tribal nations, as their legal rights may be limited to the territory within the reservation boundaries.

Beyond legal considerations, many indigenous peoples also have a strong spiritual and cultural connection to the land on which they reside or to their traditional homelands. For many indigenous peoples, their spirituality is intimately connected to the Earth and their environment. ${ }^{59}$ As a result, as the effects of climate change ravage their environment, indigenous peoples may experience both a physical and spiritual loss as a consequence of the negative impact to the environment. Similarly, because of the close spiritual connection that many indigenous peoples have with the environment, their culture and traditions are also intimately connected to the larger environment. ${ }^{60}$ It is commonplace in many indigenous communities for annual traditions and customs to be tied to certain environmental occurrences. As climate change threatens to dramatically change the environment, culture and tradition that is tied to environmental occurrences is threatened.

These commonalities that indigenous communities experience, as briefly outlined above, may relate to another common experience shared by indigenous peoples - colonization and oppression from a foreign civilization. ${ }^{61}$ Foreign nations colonized many indigenous communities. Because of such colonization and resulting oppression by the dominant society, these indigenous communities were often placed in "less

55. See COHEN'S HaNdBoOK OF Federal INDIAN LAW $§ 1.03$ (Nell Jessup Newton ed., 2005) [hereinafter COHEN'S HANDBOOK].

56. Id. $\S 7.06$.

57. Id.

58. Id.

59. Not every indigenous person has a close connection with his or her environment. However, based on Professor Kronk's experience, indigenous peoples are more likely than those of the dominant society to have a close connection, both spiritually and culturally, to the earth and the environment.

60. Tsosie, supra note 1 , at 1666 ("[M]any existing sources of international law concerning indigenous human rights recognize that the cultural survival of indigenous peoples is centrally linked to the integrity of their land base." (citing Armstrong Wiggins, Indian Rights and the Environment, 18 YALE J. INT'L L. 345, 347-48 (1993))).

61. See, e.g., Carmen G. Gonzalez, Markets, Monocultures, and Malnutrition: Agricultural Trade Policy Through an Environmental Justice Lens, 14 MiCH. ST. J. INT'L L. 345, 378-79 (2006) (suggesting that through colonization foreign communities subjugated indigenous communities). 
desirable" locations within the new nation. ${ }^{62}$ This historical displacement has resulted in many indigenous communities finding themselves in physical locations that are more susceptible to the effects of climate change, as previously discussed. ${ }^{63}$ Moreover, for those indigenous communities that were completely uprooted and moved to areas outside of their traditional homelands, they may now find themselves separated from the natural resources and options that would have otherwise made it easier for the indigenous community to adapt to the changing climate. ${ }^{64}$ Historical colonization and oppression that many indigenous communities have faced may have weakened these communities both spiritually and physically, ${ }^{65}$ wich in turn also may make it more difficult for such communities to adapt to the environmental stresses related to climate change. In short, many indigenous peoples have a similar history of colonization and oppression, which has resulted in their increased vulnerability given their physical locations and limitations on potential adaptation.

There is also some commonality in the public international law applicable to indigenous peoples. Notably, the United Nations Declaration on the Rights of Indigenous Peoples (UNDRIP) addresses international expectations of the basic rights enjoyed by indigenous peoples. $^{67}$ Although not a binding legal document, UNDRIP is helpful in providing a baseline as to what the United Nations and its member states believe are the rights (or should be the rights) of indigenous peoples. ${ }^{68}$ Moreover, UNDRIP may prove helpful to indigenous peoples, as many

62. For an example of this reality, see COHEN's HANDBOOK, supra note 55, $\S$ 1.01-.07.

63. See Sara C. Aminzadeh, Note, A Moral Imperative: The Human Rights Implications of Climate Change, 30 HASTINGS INT'L \& COMP. L. REv 231, 255 (2006).

64. Kristy Galloway, advance Guard: Climate Change Impacts, adaptation, Mitigation AND INDIGENOUS PEOPLeS 21-22 (2010), available at http://www.ias.env.edu/ resource_centre/UNU_Advance_Guard_Compendium_2010_final_web.pdf.

65. See Elizabeth Burleson \& Stephanie Dodson Dougherty, Arctic Justice: Addressing Persistent Organic Pollutants, 30 LAW \& INEQ. 57, 88 (2012) ("The manifest destiny or colonization mentality has spelled doom for natives throughout history-from conquistadorborne diseases bringing the fall of the Aztecs, to the extermination campaign of Pygmies by other African nationalities, to the forced displacement of North American natives from across the continent into reservations." (citation omitted)).

66. This is not to suggest that indigenous communities are victims of foreign governments. Rather, the purpose of this paragraph is to show that there is some commonality of historical experience among indigenous communities and that these experiences are important when considering the impacts of climate change on such communities as well as potential legal responses to such impacts.

67. See Declaration on the Rights of Indigenous Peoples, G.A. Res. 61/295, Annex, U.N. Doc. A/RES/61/295 (Oct. 2, 2007).

68. See id. 
nation-states with large indigenous populations, such as Australia, Canada, New Zealand, and the United States, signed the Declaration. ${ }^{69}$

Of particular importance here are UNDRIP's statements with regard to indigenous self-determination, property, and redress. UNDRIP article 3 states, "Indigenous peoples have the right to self-determination." UNDRIP article 8 states, "Indigenous peoples and individuals have the right not to be subjected to forced assimilation or destruction of their culture." UNDRIP article 10 states, "Indigenous peoples shall not be forcibly removed from their lands or territories. No relocation shall take place without the free, prior and informed consent of the indigenous peoples concerned and after agreement on just and fair compensation and, where possible, with the option of return." ${ }^{\text {"72 }}$ UNDRIP article 26 states, "Indigenous peoples have the right to the lands, territories and resources which they have traditionally owned, occupied or otherwise used or acquired .... States shall give legal recognition and protection to these lands, territories and resources. ${ }^{973}$ And, finally, UNDRIP article 28 states:

Indigenous peoples have the right to redress, by means that can include restitution or, when this is not possible, just, fair and equitable compensation, for the lands, territories and resources which they have traditionally owned or otherwise occupied or used, and which have been confiscated, taken, occupied, used or damaged without their free, prior and informed consent. ${ }^{74}$

Climate change has the potential to impact all of these rights of indigenous peoples, as climate change threatens indigenous land, which is often uniquely connected to indigenous identity and cultural and natural resources. As a result, climate change potentially affects the very ability of some indigenous communities to self-determine their identity and culture. UNDRIP is, therefore, very likely to be part of any discussion of the law applicable to situations involving indigenous communities and threats related to climate change. ${ }^{75}$

69. Indigenous Rights Declaration Endorsed by States, UNTED NATIONS OFFICE OF THE HIGH COMMISSIONER FOR HUMAN RIGHTS (Dec. 23, 2010), http://www.ohchr.org/EN/News Events/Pages/Indigenousrightsdeclarationendorsed.aspx.

70. G.A. Res. $61 / 295$, supra note 67 , art. 3.

71. Id. art. 8.

72. Id. art. 10.

73. Id. art. 26 .

74. Id. art. 28.

75. For further discussion of UNDRIP and other international law protections for indigenous peoples, see Lillian Aponte Miranda, Introduction to Indigenous Peoples' Status and Rights Under International Human Rights Law, in Climate Change AND INDIGENOUS PEOPLeS: THE SEARCH FOR LEGAL REMEDIES, supra note *, ch. 3. 


\section{LEGAL RESPONSES AT THE DOMESTIC, REgIONAL, AND INTERNATIONAL LEVELS}

Just as some commonality among the experiences of indigenous peoples facing the impacts of climate change exists, common trends also exist in the legal responses to these experiences. This special Issue of the Tulane Environmental Law Journal will address various legal tools available to indigenous peoples to respond to climate change impacts at the domestic and international levels. In considering the extent of legal options available to indigenous peoples, however, recognizing emerging global trends in legal strategies is helpful. In particular, a trend of indigenous peoples relying on litigation to address the devastating impacts of climate change is developing, which parallels a similar increase in climate change litigation in many nation-states. ${ }^{76}$ In particular, three types of law suits are generally used by indigenous communities challenging those entities responsible for emitting greenhouse gas emissions, which are linked to climate change: (1) law suits based on procedural rights, (2) law suits based on common law legal principles, and (3) law suits based on public international law."

With regard to law suits based on procedural rights, UNDRIP recognizes that indigenous peoples should have the right to participate in policy and law making related to matters affecting indigenous communities, should such communities choose to participate. ${ }^{78}$ Although not every nation-state has adopted laws that allow for such participation, ${ }^{79}$ some do have such laws. For example, in the United States, indigenous peoples may use the National Environmental Policy Act (NEPA) to submit comments to the relevant federal agency and then ensure that the

76. Aminzadeh, supra note 63, at 233-34 ("In 2004 and 2005, courts in Australia, Canada, New Zealand, Nigeria, and the United States heard climate change cases, and a number of cases are currently pending in both the European Union and the United States." (citation omitted)). For a discussion of climate change litigation in the indigenous peoples context, see Hari M. Osofsky, Complexities of Addressing the Impacts of Climate Change on Indigenous Peoples Through International Law Petitions: A Case Study of the Inuit Petition to the InterAmerican Commission on Human Rights, in Climate Change and Indigenous Peoples: The SEARCH FOR LEGAL REMEDIES, supra note *, ch. 15; Keely Boom, The Rising Tide of International Climate Litigation: An Illustrative Hypothetical of Tuvalu v. Australia, in CLIMATE Change and Indigenous Peoples: The Search for Legal Remedies, supra note *, ch. 19.

77. See Michael B. Gerrard, Introduction and Overview, in Global Climate Change AND U.S. LAW 1, 21 (Michael B. Gerrard ed., 2007).

78. See G.A. Res. 61/295, supra note 67, art. 5.

79. Tsosie, supra note 1 , at 1635 ("The Consortium [International Climate Justice Network] noted that local communities, including indigenous communities, are not part of the global process to address climate change even though they are the most affected." (citation omitted)). 
agency at least considers the community's concern. ${ }^{80}$ In this manner, American indigenous communities can ensure that they have an opportunity to comment on projects that could potentially contribute to increased greenhouse gas emissions and, as a result, climate change.

In countries that utilize principles of common law, such as Australia, Canada, New Zealand, and the United States, indigenous communities can turn to the common law of public nuisance as the basis of claims against emitters of greenhouse gases. An example of such a law suit is the one brought by the Native Village of Kivalina, located near the Arctic Circle in Alaska. ${ }^{81}$ The Native Village of Kivalina is a selfgoverning, federally recognized Tribe. ${ }^{82}$ Historically, sea ice provided a protective barrier for Kivalina against winter storms. ${ }^{83}$ However, because of a warming environment related to climate change, the sea ice that traditionally protected the community is melting and, as a result, Kivalina is experiencing a "massive erosion problem." storms battering the Village has increased, which only exacerbates the problem of erosion. ${ }^{85}$ Kivalina argues that the increased erosion and intensity of sea storms is related to climate change. ${ }^{86}$

In light of the substantial injury Kivalina is currently suffering and the impending loss of the land on which the Nation is located, Kivalina filed a complaint in the United States District Court for the Northern District of California on February 26, 2008, against several private entities that allegedly contribute significantly to climate change through their emissions of greenhouse gases. ${ }^{87}$ Kivalina based its complaint on claims of federal common law of public nuisance, state private and public nuisance, civil conspiracy, and concert of action. ${ }^{88}$ In relevant part, Kivalina requested monetary damages for current injuries sustained, as well as a declaratory judgment "for such future monetary expenses and

80. See 42 U.S.C. $\$ \S 4321-4370$ (2006).

81. Complaint at 1, Native Village of Kivalina v. ExxonMobil Corp., 663 F. Supp. $2 d 863$ (N.D. Cal. 2009) (No. 4:08-cv-01138-SBA), 2008 WL 594713.

82. Id. at 4 .

83. Id.

84. Id. at $1-2$.

85. See id. at $45-46$.

86. Id. at 45.

87. Kivalina's Complaint asserts, "Defendants in this action include many of the largest emitters of greenhouse gases in the United States." Id. at 1 . The complaint details the actual greenhouse gas emissions for each defendant during certain years. Id. at 5-30. For example, in 2006, BP emitted " 65 million tons of carbon dioxide equivalent greenhouse gases," Chevron emitted "68 million tons of carbon dioxide equivalent," and ConocoPhillips emitted "62.3 million tons." Id. at 6-8.

88. Id. at $62,64,66$. 
damages as may be incurred by Plaintiffs in connection with the nuisance of global warming.",89

In Kivalina, the Northern District of California granted the defendants' motion to dismiss for lack of subject matter jurisdiction because the federal common law claim for public nuisance is barred by the political question doctrine, and the plaintiffs lacked standing. ${ }^{\circ 0}$ The Village of Kivalina appealed the district court's decision to the United States Court of Appeals for the Ninth Circuit. The Ninth Circuit upheld the dismissal of the Village of Kivalina's suit, holding that the federal Clean Air Act displaced federal common law public nuisance claims for climate change impacts." Relying heavily on the United States Supreme Court's recent decision in American Electric Power Co. v. Connecticut, ${ }^{92}$ the court reasoned, "If Congress has addressed a federal issue by statute, then there is no gap for federal common law to fill."${ }^{\prime 93}$

Finally, indigenous peoples may be able to turn to public international law as the basis for a law suit to protect the community from the effects of climate change. ${ }^{94}$ These claims may be brought in either a domestic court or an international court.

In June 2005, communities from the Niger Delta filed a case against Shell, ExxonMobil, ChevronTexaco, the Nigerian National Petroleum Corporation, and the Nigerian government in the Federal High Court of Nigeria to stop gas flaring. ${ }^{95}$ This case focused on air and water pollution, even though the practice of gas flaring also causes more greenhouse gas emissions than all other sources in sub-Saharan Africa combined. ${ }^{96}$ The Niger Delta communities contended that "the practice of gas flaring and failure to undergo environmental impact assessments

89. Id. at 67.

90. Native Village of Kivalina v. ExxonMobil Corp., 663 F. Supp. 2d 863, 868 (N.D. Cal. 2009), aff'd, 696 F.3d 849 (9th Cir. 2012). 2012)

91. Native Village of Kivalina v. ExxonMobil Corp., 696 F.3d 849, 857-58 (9th Cir.

92. 131 S. Ct. 2527 (2011).

93. Kivalina, 696 F.3d at 856 (citing City of Milwaukee v. Illinois, 451 U.S. 304, 313-14 (1981)). On November 27, 2012, the Ninth Circuit denied Kivalina's petition for rehearing en banc. Native Village of Kivalina v. ExxonMobil Corp., No. 09-17490 (9th Cir. Nov. 27, 2012).

94. Claims based on public international law, and human rights law in particular, may prove to be stronger than claims based solely on international law. Tsosie, supra note 1, at 1661 ("He points out, however, that 'if international environmental law is weak, international human rights law is, by comparison, robust,' which has led scholars to advocate for international human rights law as a mechanism to litigate climate justice issues." (quoting Eric A. Posner, Climate Change and International Human Rights Litigation: A Critical Appraisal 3 (John M. Olin Law \& Econ. Working Paper No. 329, Jan. 2007))).

95. Aminzadeh, supra note 63, at 237 (citing Gbemre v. Shell Petroleum Dev. Co., [2005] No. FHC/B/CS/53/05 AHRLR 151 (NgHC 2005) (Nigeria)).

96. Id. at 238. 
violated Nigerian gas flaring regulations."97 Most significantly, the communities asserted that their human rights had been violated. ${ }^{98}$ The communities cited climate change as a harm caused by the flaring. ${ }^{99}$ The Court ordered the cessation of gas flaring in the Niger Delta community because it "violates guaranteed constitutional rights to life and dignity." Thus, "[t]he Nigerian case is one of the first where a national court held that climate change, like other environmental issues, may implicate human rights." ${ }^{\text {"101 }}$ The Nigerian lawsuit is, therefore, an example of an indigenous community using public international law to buttress its claim in a domestic court. ${ }^{102}$

Similar claims have been brought in international fora as well. One example is the Inuit Circumpolar Conference's petition to the InterAmerican Commission on Human Rights (IACHR). ${ }^{103}$ In 2005, the Inuit "filed a petition with the IACHR. The petition claimed that the United States' climate change policy violated the Inuit's human rights," including the right to property, life, and health. ${ }^{104}$ Although the IACHR declined to consider the merits of the petition, the claim is still notable because it was the first such claim brought by an indigenous community against a nation-state based on the nation-state's alleged contribution to climate change from its greenhouse gas emissions. ${ }^{105}$ The petition was also notable because it brought global attention to the issue of the impacts of climate change on indigenous peoples.

Despite legal differences between applicable domestic laws, indigenous peoples may still utilize litigation as part of a legal strategy to help address the effects of climate change. To date, some indigenous communities have accomplished this through one of three types of lawsuits, as explained above.

97. Id. (citation omitted).

98. See id. (citation omitted).

99. Id. .

100. Id. (citing Gbemre, [2005] AHRLR 151).

101. Id.

102. See Amy Sinden, An Emerging Human Right to Security from Climate Change: The Case Against Gas Flaring in Nigeria, in AdJUdicating Climate Change: STATE, NaTiONAL, AND INTERNATIONAL APPROACHES 173, 173-74 (William C.G. Burns \& Hari M. Osofsky eds., 2009).

103. Aminzadeh, supra note 63, at 239.

104. Id. (citing Petition to the Inter-American Commission on Human Rights Seeking Relief from Violations Resulting from Global Warming Caused by Acts and Omissions of the United States (submitted Dec. 7, 2005), available at http://www.ciel.org/Publications/ICC_ Petition_7Dec05.pdf).

105. For a detailed discussion of the Inuit petition, see Osofsky, supra note 76, ch. 15. 


\section{CONCLUSION}

Each indigenous community is unique in its location, customs, language, laws, religion, and culture. Yet, despite these poignant differences, indigenous communities all face the threat of climate change. There is commonality among indigenous communities because many of these communities face increased vulnerability due to their location and strong connection, both culturally and legally, to the land. In response to this commonality of experience, indigenous communities around the world are seeking legal remedies. This special edition of the Tulane Environmental Law Journal explores many of these efforts. ${ }^{106}$

106. For a fuller discussion of the impacts of climate change on indigenous peoples and potential legal solutions to these impacts, see generally CLIMATE CHANGE AND INDIGENOUS PEOPles: THE SeARCH FOR Legal Remedies, supra note *. 
